\title{
The Effect of Labor Unions and Company Management on Employee Welfare in the Mediation of the Work Environment at Pt Transportasi Jakarta
}

\author{
Kemal Pradana \\ Universitas Krisnadwipayana \\ Campus Unkris Jatiwaringin \\ PO BOX 7774/Jat CM Jakarta 13077, Indonesia \\ Email:wijayakema19@gmail.com \\ Indonesia \\ Bomer Pasaribu \\ Universitas Krisnadwipayana \\ Campus Unkris Jatiwaringin \\ PO BOX 7774/Jat CM Jakarta 13077, Indonesia \\ Email: bpasaribu22@gmail.com \\ Indonesia \\ Iwan Kurniawan Subagja \\ Universitas Krisnadwipayana \\ Campus Unkris Jatiwaringin \\ PO BOX 7774/Jat CM Jakarta 13077, Indonesia \\ Email: iwankurniawan@unkris.ac.id \\ Indonesia
}

\section{A R T I C L E I N F O \\ Article history: \\ Received: \\ Revised: \\ 30 Jan 2022 \\ 19 Feb 2022 \\ 26 Feb 2022 \\ Accepted: 28 Feb, 2022 \\ DOI: 10.47742/ijbssr.v3n2p2}

\section{(c) (†)}

https://creativecommons.org/licenses/by/4.0/

\section{A B S T R A C T}

This study aims to: 1) analyze the effect of trade unions and company management on the work environment 2) analyze the effect of trade unions and company management on employee welfare, 3) analyze the effect of the work environment on employee welfare, 4) analyze the influence of trade unions and company management on employee welfare. employee welfare through the work environment. The research was conducted at PT Transport Jakarta with a research sample of 95 employees. The sampling technique used was simple random technique. The data analysis method used descriptive analysis and path analysis.

The results showed that: 1) there was an influence of trade unions and company management on the work environment, 2) there was an influence of trade unions and company management on employee welfare, 3) there was an influence of the work environment on employee welfare, 4) the work environment did not play a role in improving employee welfare. trade unions and company management on the welfare of employees at PT Transport Jakarta.

\section{Keywords: union, company management, work environment, employee welfare}

\section{Introduction}

Public transportation has started to be widely used by the community because the current means of transportation is made much safer and more comfortable, especially in the capital city public transportation has become part of the need and many advantages can be obtained from using public transportation, namely saving costs. and save time compared to using private transportation. In DKI Jakarta there are many means of public transportation such as MRT, LRT, and Transjakarta. For now, we will discuss PT Transportation Jakarta (Transjakarta/Busway).

Transjakarta is the first Bus Rapid Transit (BRT) transportation system in Southeast and South Asia which has been operating since 2004 in Jakarta, Indonesia. TransJakarta is designed as a mode of mass transportation to support the capital's very busy activities. With the longest track in the world (251.2 $\mathrm{km}$ ), and has 260 bus stops spread across 13 corridors, Transjakarta initially operates from Pkl. 05.00-Pkl. 22.00 WIB, now operating 24 hours.

For now, Transjakarta is the number 1 means of transportation in the capital city of DKI Jakarta with the number of customers reaching 1 million customers per day. And for now, starting from 24-04-2020 PT Transport Jakarta has 9,501 employees which makes Transjakarta one of the company's largest transportation in DKI Jakarta and even Indonesia.

With the increasing number of workers at PT Transport Jakarta, sometimes creating a gap between management and workers, various problems arise for workers, especially those related to welfare. It is undeniable that, among the many issues surrounding workers, the issue of welfare is sensitive. Problems are always discussed because they involve a person's survival. 


\title{
International Journal of Business and Social Science Research
}

\author{
Vol: 3, Issue: 2 \\ February/2022 \\ DOI: http://dx.doi.org/10.47742/ijbssr.v3n2p2 \\ https://ijbssrnet.com/index.php/ijbssr
}

From year to year, the classic problems that arise are interns demanding to be made contract employees, prosecution of contract employees who want to be appointed as permanent employees, demands for overtime pay, and much more. This is because the compensation they can feel is not commensurate with their work. Especially with the contract system that has been carried out so far at the PT Transportation Jakarta company. To deal with the company, these workers formed workers' organizations called trade unions. By association and gathering, it is hoped that their bargaining position in front of companies and the government will be stronger. The workers also held rallies to fight for their welfare. It is known that Transjakarta has three trade unions, namely SPDT (Union of Transportation Aerospace Workers), SPTJ (Jakarta Transportation Workers Union), and SPTI (Indonesian Transportation Workers Union). These three unions serve as bridges for employees to express their aspirations.

\section{Literature Review}

\section{Labor Union}

Based on the general provisions of Article 1 of the 2003 Manpower Act No. 17, a labor union/labor union is an organization formed from, by, and for workers both in the company and outside the company, which is free, open, independent, democratic, and responsible to fight for, defend and protect the rights and interests of workers and improve the welfare of workers and their families.

Under article 102 of the 2003 Manpower Law, in carrying out industrial relations, workers and trade unions have the functions of carrying out work under their obligations, maintaining order for the sake of production continuity, channeling aspirations democratically, developing skills and expertise as well as participating in advancing the company and fighting for welfare members and their families.

\section{Company Management}

Management is a procedure that is carried out to achieve the goals of an institution by working in a working tap. Experts have different opinions on defining management. In the following, several definitions of management will be presented from several perspectives.

a) Understanding management in terms of art is the art of completing work through other people. This understanding was put forward by Mary Parker Follet (Tripathi and Reddy, 2008).

b) Understanding management in terms of knowledge is a field of knowledge that tries to systematically understand why and how humans work together to produce something beneficial to humanity. This understanding was put forward by Luther Gulicktri (Tripathi and Reddy, 2008).

Understanding management in terms of the process is planning, organizing, leadership, and supervising the activities of members as well as the purpose of using the organization that has been determined. This definition was put forward by (Stoner, Gilbert, and Freeman, 2012).

\section{Work Environment}

The work environment is the social, psychological, and physical life in the company that affects workers in carrying out their duties. Human life is inseparable from the various circumstances of the surrounding environment, between humans and the environment there is a very close relationship. In this case, humans will always try to adapt to various circumstances in the surrounding environment.

Likewise, when doing work, employees as humans cannot be separated from the various circumstances around where they work, namely the work environment. During their work, each employee will interact with various conditions in the work environment.

The work environment is something that is around the workers and that affects them in carrying out the tasks assigned (Nitisemito, 2000). Furthermore, according to Sedarmayati (2013), the work environment is the total tools and materials encountered, the surrounding environment in which a person works, work methods, and work arrangements both as individuals and as groups.

\section{Employee Welfare}

According to Hasibuan (2001) welfare is a complete remuneration (material and non-material provided by the company based on policy. The aim is to maintain and improve the physical and mental condition of employees so that their productivity increases.

Welfare is to be viewed as further assistance money to employees. Mainly payments to those who are sick, assistance money for employee savings, distribution in the form of shares, insurance, hospital treatment, and pensions

The importance of welfare programs provided to employees to improve employee work discipline stated by Hasibuan (2001) is: "Providing welfare will create calm, work enthusiasm, dedication, discipline and a loyal attitude towards the company so that labor turnover is relatively low." sufficient welfare, then they will be calmer in carrying out their duties. With this calm, it is hoped that employees will be more disciplined.

\section{Research Methods}

\section{Time and Location of Research}

In this section, it is explained and stated the time indicating when (month and year) and the place where the research was carried out.

1. Research time

The time used by researchers in this study was from May 2020 to completion.

\section{Research location}

The research location is at the office of PT Transport Jakarta, which is located at Jl. Lt. Gen. Sutoyo No. 1 Cawang, East Jakarta.

\section{Research Design}

This study uses quantitative research which will be described in a description in the study of the data. The research design uses a formal research procedure that contains a clear definition of the research objectives and information needs. With the technique of filling out the questionnaire. The data that has been collected is then combined based on the results of statistical tests so that at the stage of compiling conclusions, the meaning of each data can be obtained. 


\section{International Journal of Business and Social Science Research}

Vol: 3, Issue: 2

February/2022

DOI: http://dx.doi.org/10.47742/ijbssr.v3n2p2

https://ijbssrnet.com/index.php/ijbssr

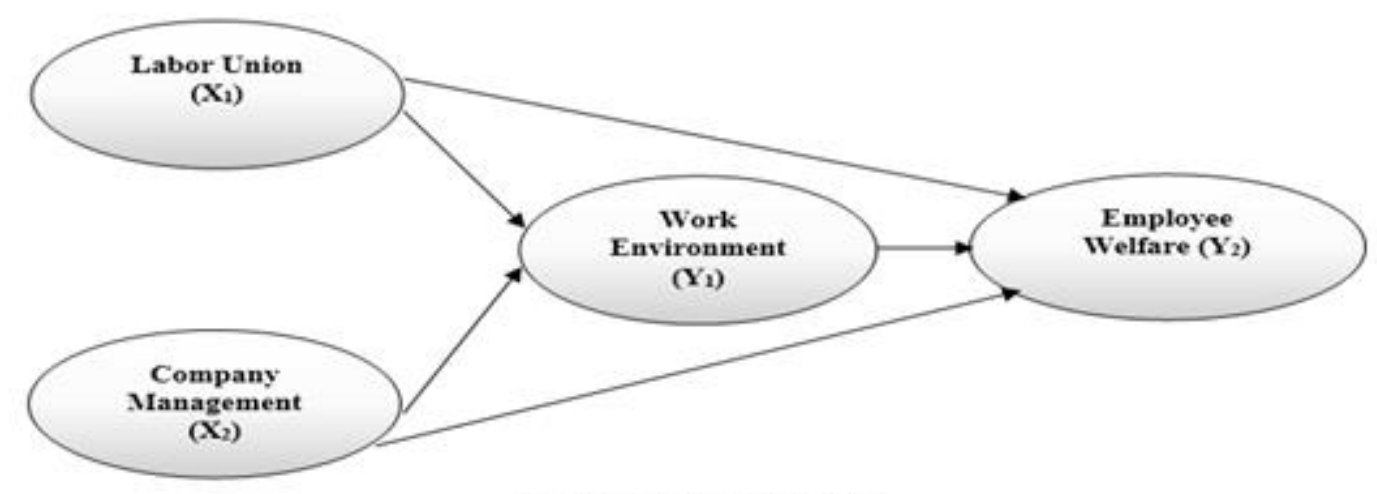

Figure 1. Research Design

\section{Population and Sample}

The population is a generalization area consisting of objects or subjects that have certain qualities and characteristics determined by researchers to be studied and then drawn conclusions (Sugiyono, 2014). The population used by the researcher in this study were 125 interns and contract employees working in the field of PT Transport Jakarta.

Sampling in this study, researchers used the probability sampling technique. While the method for taking samples uses simple random sampling (simple random sampling). According to Sugiyono (2014), a questionnaire is a data collection technique that is carried out by giving a set of questions or written statements to respondents to answer. In this study, questionnaires were distributed to contract employees and interns who served in the field at PT Transport Jakarta. The number of samples taken as many as 95 employees at PT Transport Jakarta.

Table 1. Test Results of Trade Unions and Company Management on the Work Environment Model Summary

\begin{tabular}{|c|c|c|c|c|}
\hline Model & R & R Square & $\begin{array}{c}\text { Adjusted R } \\
\text { Square }\end{array}$ & $\begin{array}{c}\text { Std. Error of the } \\
\text { Estimate }\end{array}$ \\
\hline 1 & $.700^{\mathrm{a}}$ & .491 & .479 & 2.67750 \\
\hline
\end{tabular}

a. Predictors: (Constant), X2, X1

Source: Primary Data processed, 2021

Table 1 shows the value of R2 (R Square) of 0.491. This R2 value Magnitude:

is used in calculating the coefficient value of e1. The coefficient Coefficiente ${ }_{1}=\sqrt{\left(1-R^{2}\right)}=\sqrt{(1-0,491)}=\sqrt{0,509}=0,713$. of $\mathrm{e} 1$ is a variant of the work environment that is not explained by the union and company management.

Table 2. Results of Work Environment Regression Analysis

Coefficients $^{\mathrm{a}}$

\begin{tabular}{|cc|c|c|c|c|c|}
\hline \multirow{2}{*}{} & \multicolumn{2}{|c|}{$\begin{array}{c}\text { Unstandardized } \\
\text { Coefficients }\end{array}$} & $\begin{array}{c}\text { Standardized } \\
\text { Coefficients }\end{array}$ & & \\
\cline { 2 - 5 } & Model & $\mathrm{B}$ & Std. Error & Beta & $\mathrm{t}$ & Sig. \\
\hline 1 & (Constant) & 8.292 & 1.314 & & 6.310 & .000 \\
& $\mathrm{X} 1$ & .175 & .263 & .602 & 3.666 & .007 \\
& $\mathrm{X} 2$ & .774 & .195 & .609 & 3.965 & .000 \\
\hline
\end{tabular}

a. Dependent Variable: Y1

Source: Primary Data processed, 2021

\section{Data Analysis Technique}

Data analysis conducted in this study is quantitative research. Therefore, the data obtained from the respondents stastical anaysis with compun Windows. The data collected will be analyzed in 3 stages, namely descriptive analysis, classical assumption test, and path analysis. Research Results and Discussion

1. Analysis of the Influence of Labor Unions and Company

The results of the regression analysis of the influence of trade unions and company management on the work environment can be seen in the table below: 


\title{
International Journal of Business and Social Science Research
}

\author{
Vol: 3, Issue: 2 \\ February/2022 \\ DOI: http://dx.doi.org/10.47742/ijbssr.v3n2p2 \\ https://ijbssrnet.com/index.php/ijbssr
}

Based on Table 2, it can be seen that the regression equation is as follows:

$$
\begin{aligned}
& Y_{1}=b_{1} X_{1}+b_{2} X_{2}+e_{1} \\
& Y_{1}=0,175 X_{1}+0,774 X_{2}+0,713 e_{1}
\end{aligned}
$$

The equation shows that:

- Each increase in 1 union will be followed by an increase in the work environment by 0.175 .

- Every time there is an increase in 1 unit of company and company management on employee welfare can be seen in management, it will be followed by an increase in the work Table 3, below:

environment of 0.774 .

\section{Table 3. Test Results of the Influence of Labor Unions and Company Management on Employee Welfare}

Model Summary

\begin{tabular}{|c|c|c|c|c|}
\hline Model & R & R Square & $\begin{array}{c}\text { Adjusted R } \\
\text { Square }\end{array}$ & $\begin{array}{c}\text { Std. Error of the } \\
\text { Estimate }\end{array}$ \\
\hline 1 & $.720^{\mathrm{a}}$ & .519 & .508 & 4.93447 \\
\hline
\end{tabular}

a. Predictors: (Constant), X2, X1

Source: Primary Data processed, 2021

Table 3 shows the value of R2 (R Square) of 0.519 . This $\mathrm{R} 2$ value is used in calculating the e2 coefficient value. The explained by the union and company management. Magnitude: Coefficient

$$
\left.\mathrm{e}_{1}=\sqrt{\left(1-R^{2}\right.}\right)=\sqrt{(1-0,519)}=\sqrt{0,481}=0,693 .
$$

Table 4. Results of Employee Welfare Regression Analysis Coefficients $^{a}$

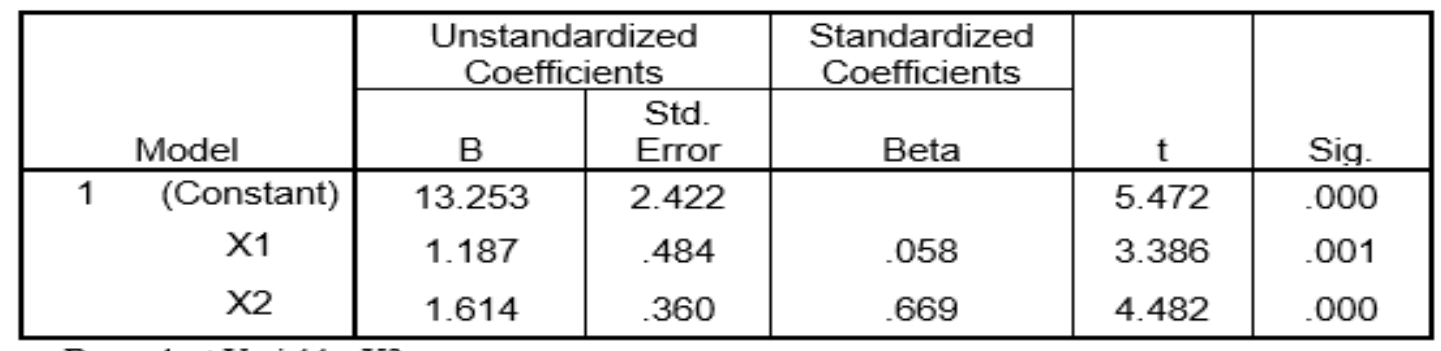

a. Dependent Variable: Y2

Source: Primary Data processed, 2021

Based on Table 4, it can be seen that the regression equation is as follows: $\mathrm{Y}_{2}=$

$$
\mathrm{b}_{1} \mathrm{X}_{1}+\mathrm{b}_{2} \mathrm{X}_{2}+\mathrm{e}_{2}
$$

$\mathrm{Y}_{2}=0,484 \mathrm{X}_{1}+0,360 \mathrm{X}_{2}+0,693 \mathrm{e}_{2}$

The equation shows that:

Every 1-unit increase in labor unions will be followed by an increase in employee welfare by 0.484 .

- Every time there is an increase in 1 unit of company management, it will be followed by an increase in employee welfare by 0.360 .
So from equation (2) it can be seen that if the union increases, the welfare of employees will increase. If knowledge management increases, employee welfare will also increase.

\section{Analysis of the Effect of the Work Environment on Employee Welfare}

The results of the analysis of the influence of the work environment on the welfare of employees can be seen in Table 5 , below:

Table 5. Test Results of the Influence of Labor Unions and Company Management on Karaywan

Welfare

Coefficients $^{\mathrm{a}}$

\begin{tabular}{|cc|c|c|c|c|c|}
\hline & \multicolumn{2}{|c|}{$\begin{array}{c}\text { Unstandardized } \\
\text { Coefficients }\end{array}$} & \multicolumn{1}{|c|}{$\begin{array}{c}\text { Standardized } \\
\text { Coefficients }\end{array}$} & \multirow{2}{*}{} & \\
\cline { 2 - 5 } & Model & $\mathrm{B}$ & Std. Error & Beta & $\mathrm{t}$ & Sig. \\
\hline 1 & (Constant) & 6.733 & 2.562 & & 2.628 & .010 \\
& Y1 & 1.463 & .125 & .772 & 11.703 & .000 \\
\hline
\end{tabular}

a. Dependent Variable: Y2

Source: Primary Data processed, 2021 


\title{
International Journal of Business and Social Science Research
}

\author{
Vol: 3, Issue: 2 \\ February/2022 \\ DOI: http://dx.doi.org/10.47742/ijbssr.v3n2p2 \\ https://ijbssrnet.com/index.php/ijbssr
}

Based on Table 5, it can be seen that the regression equation is as follows:

$\begin{array}{ll}\text { - } \quad \mathrm{Y} 2 & =\mathrm{b} 1 \mathrm{Y} 1 \\ \mathrm{Y} 2 & =125 \mathrm{Y} 1\end{array}$
The equation shows that:

Every 1-unit increase in the work environment will be followed by an increase in employee welfare of 0.125 . Based on equations (1), (2) and (3), a path analysis model is obtained as follows:

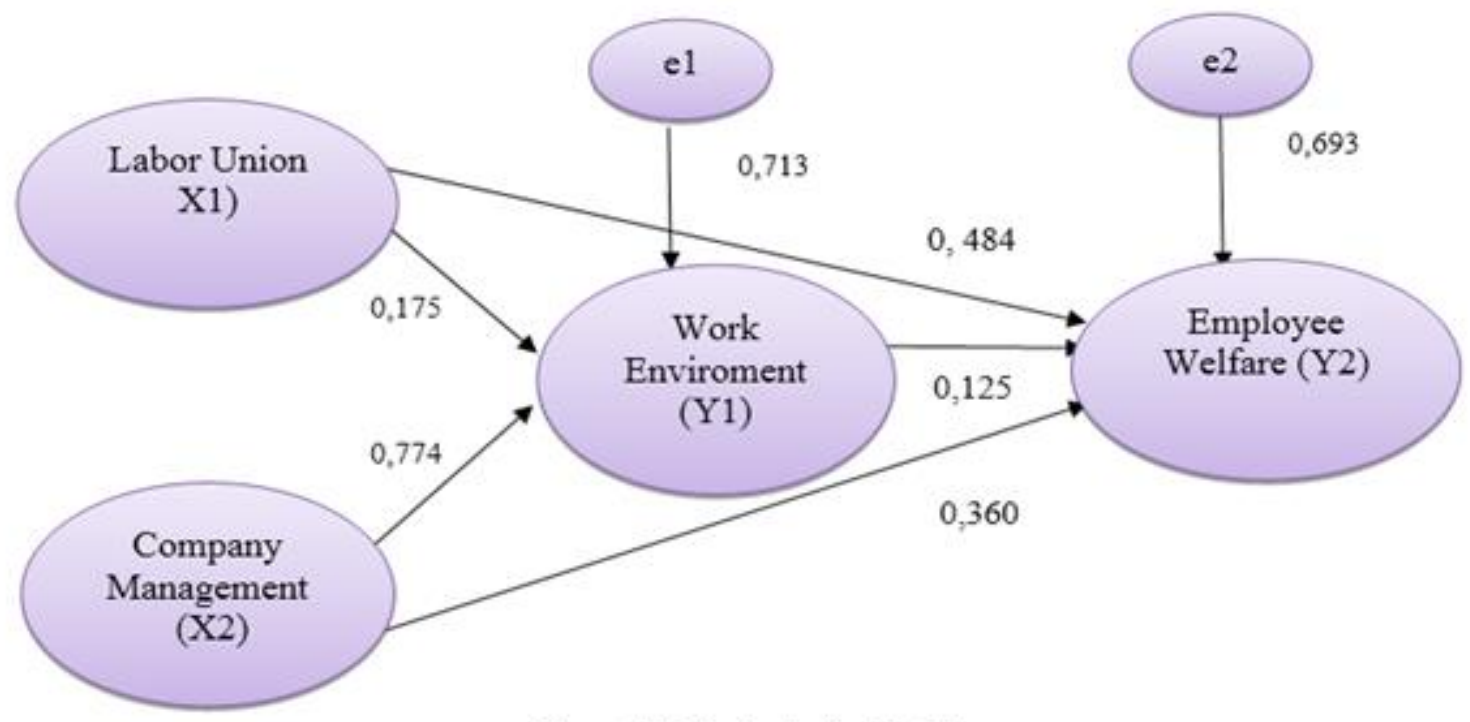

Figure 2. Path Analysis Model

Hypothesis Test

To find this out, it is necessary to use the $\mathrm{F}$ test. The following is 1. Allegedly there is an Influence of Trade Unions and a test of each variable:

Company Management on the Work Environment

Table 6. F Test Results the Influence of Labor Unions and Company Management on the Work Environment

$\mathrm{ANOVA}^{\mathrm{a}}$

\begin{tabular}{|cc|c|c|c|c|c|}
\hline & & $\begin{array}{c}\text { Sum of } \\
\text { Squares }\end{array}$ & df & Mean Square & F & Sig. \\
\hline 1 & Regression & 635.082 & 2 & 317.541 & 44.293 & $.000^{\mathrm{b}}$ \\
& Residual & 659.550 & 92 & 7.169 & & \\
& Total & 1294.632 & 94 & & & \\
\hline
\end{tabular}

a. Dependent Variable: Y1

b. Predictors: (Constant), X2, X1

Source: Primary Data processed, 2021

From Table 6, it is found that the F-count for the variable 2. Allegedly There is an Influence of Labor Unions and union and company management is 44,293, while the F-table is Company Management on Employee Welfare

3.94. Thus F-count > F-Table. Thus $\mathrm{H} 0$ is rejected and $\mathrm{H} 1$ is

To test the effect of trade unions and company accepted at the real level. This gives the conclusion that the union management on employee welfare, the $\mathrm{F}$ test is carried out. The and company management affect employee welfare. Thus the first following are the results of the $\mathrm{F}$ test:

hypothesis is tested.

Table 7. F Test Results the Influence of Labor Unions and Company Management on Employee Welfare

ANOVA $^{2}$

\begin{tabular}{|cc|c|c|c|c|c|}
\hline & Model & $\begin{array}{c}\text { Sum of } \\
\text { Squares }\end{array}$ & df & Mean Square & F & Sig. \\
\hline 1 & Regression & 2414.793 & 2 & 1207.397 & 49.587 & $.000^{\mathrm{b}}$ \\
& Residual & 2240.112 & 92 & 24.349 & & \\
& Total & 4654.905 & 94 & & & \\
\hline
\end{tabular}

a. Dependent Variable: Y2

b. Predictors: (Constant), X2, X1

Source: Primary Data processed, 2021 


\title{
International Journal of Business and Social Science Research
}

\author{
Vol: 3, Issue: 2 \\ February/2022 \\ DOI: http://dx.doi.org/10.47742/ijbssr.v3n2p2 \\ https://ijbssrnet.com/index.php/ijbssr
}

The results of the F-test for the variable union and 3. It is suspected that there is an influence of the work company management were 49,587 and the F-table was 3,94. F- environment on the welfare of employees

count > F-table which means $\mathrm{H} 0$ is rejected and $\mathrm{H} 1$ is accepted.

To test the effect of the work environment on the welfare This gives the conclusion that the union and company of employees, the t-test is carried out. The following are the management affect employee welfare. Thus the second results of the t-test:

hypothesis is tested.

Table 8. Results of t-test The Effect of Work Environment on Employee Welfare Coefficients $^{\mathrm{a}}$

\begin{tabular}{|c|c|c|c|c|c|}
\hline \multirow[b]{2}{*}{ Model } & \multicolumn{2}{|c|}{ Unstandardized Coefficients } & \multirow{2}{*}{$\begin{array}{c}\begin{array}{c}\text { Standardized } \\
\text { Coefficients }\end{array} \\
\text { Beta } \\
\end{array}$} & \multirow[b]{2}{*}{$\mathrm{t}$} & \multirow[b]{2}{*}{ Sig. } \\
\hline & B & Std. Error & & & \\
\hline (Constant) & 6.733 & 2.562 & & 2.628 & .010 \\
\hline Y1 & 1.463 & .125 & .772 & 11.703 & .000 \\
\hline
\end{tabular}

a. Dependent Variable: Y2

Source: Primary Data processed, 2021

The results of the t-test for the work environment variable obtained a t-count value $=11.703$ and a t-table of 1.663 . This means that $\mathrm{t}$-count $>\mathrm{t}$-table $(11.703>1.663)$, which means $\mathrm{HO}$ is rejected and $\mathrm{H} 1$ is accepted. This gives the conclusion that the work environment affects the welfare of employees. Thus the third hypothesis is tested.

4. It is suspected that there is an influence of labor unions and company management on employee welfare through the work environment

- $\mathrm{X}_{1} \rightarrow \mathrm{Y}_{1} \rightarrow \mathrm{Y}_{2}=\left(\rho \mathrm{y}_{1} \mathrm{x}_{1}\right) \times\left(\rho \mathrm{y}_{2} \mathrm{y}_{1}\right)=0,175 \times 0,125=0,022$

- $\mathrm{X}_{2} \rightarrow \mathrm{Y}_{1} \rightarrow \mathrm{Y}_{2}=\left(\rho \mathrm{y}_{1} \mathrm{x}_{2}\right) \times\left(\rho \mathrm{y}_{2} \mathrm{y}_{1}\right)=0,774 \times 0,125=0,097$

In the trade union variable, the indirect influence value is

obtained from the path coefficient value $\mathrm{y} 1 \mathrm{x} 1$ multiplied by the path coefficient value $y 2 y 1$. The multiplication result shows that the value of the coefficient of indirect influence is smaller than the value of the coefficient of direct influence.

In the knowledge management variable, the indirect influence value is obtained from the path coefficient value $\mathrm{y} 1 \mathrm{x} 2$ multiplied by the path coefficient value y2y1. The multiplication result shows that the value of the coefficient of indirect influence is smaller than the value of the coefficient of direct influence.

This shows that the work environment cannot mediate, namely trade unions and knowledge management in influencing employee welfare. Thus the fourth hypothesis is not tested.

\section{Discussion}

\section{The Influence of Trade Unions and Company Management} on the Work Environment at PT Transport Jakarta

Based on the descriptive analysis of the trade union variable, it shows that the union members assist employees at PT Transport Jakarta in conveying their aspirations regarding working hours, payment of wages, and leave entitlements. The company management variable shows that the company's activities are carried out according to schedule, the supervision carried out by the company runs in an orderly manner, the company already has divisions according to needs, and the company has regular planning. The work environment variable shows that the company has a well-maintained work center, has equipment for employees that is maintained and sufficient.
Working at PT Transport Jakarta is very enjoyable because it suits the temperature and the appropriate lighting. Besides that, the family at this company is very supportive of the work of employees, the communication that exists in the company is very good and the control of employees who work for the company is very good at PT Transport Jakarta.

Based on the results of the path analysis, it shows that the union and company management contribute to the improvement of the work environment of PT Transport Jakarta. The results of this study are in line with the results of research conducted by Ningsih and Utami (2015); Santoso and Djastuti (2011); Ernita (2018).

\section{The Influence of Labor Unions and Company Management} on Employee Welfare at PT Transport Jakarta

Based on the descriptive analysis of the trade union variable, it shows that the union members assist employees at PT Transport Jakarta in conveying their aspirations regarding working hours, payment of wages, and leave entitlements. The company management variable shows that the company's activities are carried out according to schedule, the supervision carried out by the company runs in an orderly manner, the company already has divisions according to needs, and the company has regular planning. The employee welfare variable shows that the salary given by the PT Transportation Jakarta company is satisfactory. PT Transport Jakarta provides a certain amount of money periodically (pension money) to employees who have stopped working, providing holiday allowances in accordance with the position/position. Likewise, the medical fees provided by the PT Transportation Jakarta company have met the needs, and PT Transportation Jakarta provides recreational programs for employees, provides a canteen/cafeteria for employees, making it easier for employees to get food during breaks. PT Transport Jakarta also provides a cooperative where employees can buy various items needed by providing credit for employees. Other facilities PT Transport Jakarta provides polyclinics for employees, room facilities, and parking spaces for employees, and PT Transport Jakarta provides insurance for employees and their families. 


\title{
International Journal of Business and Social Science Research
}

\author{
Vol: 3, Issue: 2 \\ February/2022 \\ DOI: http://dx.doi.org/10.47742/ijbssr.v3n2p2 \\ https://ijbssrnet.com/index.php/ijbssr
}

Based on the results of the regression analysis showed that the union and company management contributed to the improvement of the welfare of the employees of PT Transport Jakarta. The results of this study are in line with the results of research conducted by Ernita (2018); Pradhanawati and Nugraha (2016); Pujiastuti (2008); Primary (2017); Arthawati (2018); Mash and Kremer (2016).

\section{The Effect of Motivation on Job Satisfaction at PT Transport Jakarta}

Based on the analysis of the description of the work environment, it shows that the company has a well-maintained work center, has equipment for employees that is maintained and sufficient. Working at PT Transport Jakarta is very enjoyable because it suits the temperature and the appropriate lighting. Besides that, the family at this company is very supportive of the work of employees, the communication that exists in the company is very good and the control of employees who work for the company is very good at PT Transport Jakarta.

The employee welfare variable shows that the salary given by the PT Transportation Jakarta company is satisfactory. PT Transport Jakarta provides a certain amount of money periodically (pension money) to employees who have stopped working, providing holiday allowances in accordance with the position/position. Likewise, the medical fees provided by the PT Transportation Jakarta company have met the needs, and PT Transportation Jakarta provides recreational programs for employees, provides a canteen/cafeteria for employees, making it easier for employees to get food during breaks. PT Transport Jakarta also provides a cooperative where employees can buy various items needed by providing credit for employees. Other facilities PT Transport Jakarta provides polyclinics for employees, room facilities, and parking spaces for employees, and PT Transport Jakarta provides insurance for employees and their families.

Based on the results of path analysis shows that the work environment contributes to the improvement of employee welfare at PT Transport Jakarta. The results of this study are in line with the results of research conducted by Ningsih and Utami (2015); Santoso and Djastuti (2011); Ernita (2018); Pradhanawati and Nugraha (2016); Pujiastuti (2008); Primary (2017); Arthawati (2018); Mash and Kremer (2016).

4. The Influence of Trade Unions and Company Management on Employee Welfare Through the Work Environment at PT Transport Jakarta

Based on the descriptive analysis of the trade union variable, it shows that the union members assist employees at PT Transport Jakarta in conveying their aspirations regarding working hours, payment of wages, and leave entitlements. The company management variable shows that the company's activities are carried out according to schedule, the supervision carried out by the company runs in an orderly manner, the company already has divisions according to needs, and the company has regular planning. The work environment variable shows that the company has a well-maintained work center, has equipment for employees that is maintained and sufficient. Working at PT Transport Jakarta is very enjoyable because it suits the temperature and the appropriate lighting. Besides that, the family at this company is very supportive of the work of employees, the communication that exists in the company is very good and the control of employees who work for the company is very good at PT Transport Jakarta.

The employee welfare variable shows that the salary given by the PT Transportation Jakarta company is satisfactory. PT Transport Jakarta provides a certain amount of money periodically (pension money) to employees who have stopped working, providing holiday allowances in accordance with the position/position. Likewise, the medical fees provided by the PT Transportation Jakarta company have met the needs, and PT Transportation Jakarta provides recreational programs for employees, provides a canteen/cafeteria for employees, making it easier for employees to get food during breaks. PT Transport Jakarta also provides a cooperative where employees can buy various items needed by providing credit for employees. Other facilities PT Transport Jakarta provides polyclinics for employees, room facilities, and parking spaces for employees, and PT Transport Jakarta provides insurance for employees and their families.

Based on the results of the path analysis, it shows that the union and company management do not have an impact on improving employee welfare through the work environment. This shows that the work environment cannot mediate, namely the union and company management in influencing the welfare of employees at PT Transport Jakarta. The results of this study are not in line with the results of research conducted by Ningsih and Utami (2015); Santoso and Djastuti (2011); Ernita (2018); Pradhanawati and Nugraha (2016); Pujiastuti (2008); Primary (2017); Arthawati (2018); Mash and Kremer (2016).

\section{Conclusions and Recommendations}

\section{Conclusion}

Based on the results of research on the effect of trade unions and company management on employee welfare mediated by the work environment at PT Transport Jakarta, the following conclusions can be drawn:

1. Based on the description analysis of the trade union variable, it shows that union members assist employees at PT Transport Jakarta in conveying aspirations regarding working hours, payment of wages, and leave entitlements.

2. The company management variable shows that the company's activities are carried out according to schedule, the supervision carried out by the company is running in an orderly manner, the company already has divisions according to needs, and the company has regular planning.

3. The work environment variable shows that the company has a well-maintained work center, has equipment for employees that is maintained and sufficient. Working at PT Transport Jakarta is very enjoyable because it suits the temperature and the appropriate lighting. Besides that, the family at this company is very supportive of the work of employees, the communication that exists in the company is very good 


\title{
International Journal of Business and Social Science Research
}

\author{
Vol: 3, Issue: 2 \\ February/2022 \\ DOI: http://dx.doi.org/10.47742/ijbssr.v3n2p2 \\ https://ijbssrnet.com/index.php/ijbssr
}

and the control of employees who work for the company is very good at PT Transport Jakarta.

4. The employee welfare variable shows that the salary given by the PT Transportation Jakarta company is satisfactory. PT Transport Jakarta provides a certain amount of money periodically (pension money) to employees who have stopped working, providing holiday allowances in accordance with the position/position. Likewise, the medical fees provided by the PT Transportation Jakarta company have met the needs, and PT Transportation Jakarta provides recreational programs for employees, provides a canteen/cafeteria for employees, making it easier for employees to get food during breaks. PT Transport Jakarta also provides a cooperative where employees can buy various items needed by providing credit for employees. Other facilities PT Transport Jakarta provides polyclinics for employees, room facilities, and parking spaces for employees, and PT Transport Jakarta provides insurance for employees and their families.

5. The results of the path analysis show that the union and company management do not have an impact on improving employee welfare through the work environment. This shows that the work environment cannot mediate, namely the union and company management in influencing the welfare of employees at PT Transport Jakarta.

\section{Suggestion}

Based on the results of research on the effect of trade unions and company management on employee welfare mediated by the work environment at PT Transport Jakarta, some suggestions can be made as follows:

1. The results of this study are expected to contribute to the knowledge, insight, and experience of researchers in the field of human resource management, especially regarding trade unions, company management, work environment, and employee welfare at PT Transport Jakarta and this research is expected to improve the work environment and welfare employees in a constructive effort towards the improvement of trade unions and company management.

2. The results of this study are expected to be used as input and reference for organizations to take policies or decisions that are deemed necessary in an effort to improve the work environment and employee welfare through efforts to improve the union and company management, taking into account the following:

a. PT Transportation Jakarta must be precise in paying wages so that they are paid every month, so there is no delay.

b. PT Transport Jakarta must carry out supervision that is carried out in an orderly and indiscriminate manner on all operations.

c. PT Transportation Jakarta must pay attention to all the facilities that have been built so that they are maintained and cared for as company assets.

d. PT Transport Jakarta must pay attention to employee salaries according to competence and education and be given rewards and punishments.

\section{References}

A, Aziz, Hidayat. 2017. Nursing research methods and Data Analysis Techniques. Jakarta: Salemba Medika.

Ahmad Ari Pratama. 2017. The Influence of Labor Unions, Organizational Culture on Employee Job Satisfaction, Case Study at Pt. Alfa Retailindo Bintaro. Essay.

Alex S. Nitisemito 2000. Personnel Management: Human Resource Management, Ed. 3, Ghalia Indonesia, Jakarta.

Anik Rotul Qori'ah, Mochammad Al Musadieq \& Arik Prasetya. 2015. The Effect of Trade Union Functions on Job Satisfaction and Monkey Motivation (Study on Permanent Employees of Production Division of Pt. Berlina Tbk. Pandaan). Journal of Business Administration (JAB). |Vol. 21 No. April 1, 2015.

Arep, Isaac and Hendri, Tanjung. 2003. Human Resource Management. Jakarta: Trisakti University.

Arthawati, S. N. 2018. The Role of Trade Unions in Encouraging Productivity and Improving the Welfare of Workers at PT Nippon Shokubai Indonesia-Cilegon. Tirtayasa Ekonomika, 13(1), 100-106.

Ayu Ernita. 2018. The Influence of Trade Unions and Industrial Relations on the Welfare of Permanent Employees at Pt Bogatama Marinusa (Bomar) Makassar. Undergraduate (S1) Thesis, Alauddin State Islamic University Makassar.

Bambang Kusriyanto. 1991. Increasing Employee Productivity. Jakarta: PT. Library of Binaman Pressindo.

Dwi Pujiastuti. 2008. The Role of Trade Unions in Creating Harmonious Industrial Relations at Pt. Karanganyar Fountain. Essay. Echdar Saban, 2017. Management and Business Research Methods. Bogor: Ghalia Indonesia.

Elifaz Eldy, Ari Pradhanawati and Hari Susanta Nugraha. 2016. The Influence of Wages, The Role of Trade Unions on Workers' Welfare Through Demonstrations at the Psp National Workers Union Pt Sai Apparel Industries. Diponegoro University Business Administration Study Program. 


\section{International Journal of Business and Social Science Research}

Vol: 3, Issue: 2

February/2022

DOI: http://dx.doi.org/10.47742/ijbssr.v3n2p2

https://ijbssrnet.com/index.php/ijbssr

Ghozali, Imam. 2011. "Application of Multivariate Analysis With SPSS Program". Semarang: Diponegoro University Publishing Agency.

Hamong Santoso and Indi Djastuti. 2011. Workers' Participation in Trade Unions. Masters Program in Management at Diponegoro University Journal of Development Economics, Volume 12 Number 2, December 2011.

Hasibuan, Malay S.P. 2001. Human Resource Management Revised Edition. Jakarta: Earth Literacy.

IG, Wursanto, 1988. Personnel Management 2, Kanisius. Malay, Yogyakarta, 1988.

Kotler, Philip and Kevin Lane Keller, 2012. Marketing Management, Issue 14, New Jersey: Prentice-Hall Published.

Mudrajad Kuncoro, 2010. "Research Methods for Business and Economics” Edition 4. Jakarta: Erlangga.

Nia Oktavia Ningsih, Mochammad Al Musadieq and Hamidah Nayati. 2015. entitled The Role of Labor Unions and Management in Fostering Industrial Relations. Journal of Business Administration (JAB). Vol. 24 No. July 1, 2015|.

Noor, Juliansyah. 2012. Research Methodology. Jakarta: Kencana Prenada Media Group.

Roni Mash \& Michal Gutman Kremer. 2016. Trade Unions: Promoting or Withholding Solutions in Management-Union Conflicts? Analysis of Employee and Manager Perceptions. Journal of Sociology and Social Work 4(1).

Schultz, D., Schultz, S. E. 2006. Psychology \& Work Today Ninth Edition. New Jersey : Pearson Education. Inc.

Sedarmayanti. 2013. Human Resources and Work Productivity. Mandar Maju, Bandung.

Sintania Syifa Nurul Aini \& M. Yahya Arwiyah. 2018. Trade Unions in Improving Employee Job Satisfaction at Pt Inti (Persero) Bandung. Journal of Business and Management Research Volume 11, No 2, August 2018, p. 73-79.

Sonhaji. 2019. The Organization of Trade Unions Against the Welfare of Workers or Laborers at PT. Apac Core Corpora. Administrative Law \& Governance Journal. Volume 2 Issue 4, Nov 2019.

Stoner, S., James A.F., Edward Freeman and Gilbert, Daniel. 2012. Management, New Jersey: Prentice Hall Inc.

Sugiyono. 2014. Educational Research Methods Quantitative, Qualitative, and R\&D Approaches. Bandung: Alphabeta.

Tripathi, P.C. and P.N. Reddy. 2008. Principles of Management. New Delhi: Tata The McGraw-Hill Company Limited.

Manpower Law 2003 No. 17. Regarding Labor Unions/Labour Unions.

UU no. 21 of 2000 concerning Labor Unions/Labour Unions.

Manpower Law, 2003 In Implementing Industrial Relations. 